Жељко С. Тешић

УДК 371.3::811.163.41+821.163.41]:004

Универзитет у Београду

Стручни рад

10.19090/mv.2016.7.235-251

Филолошки факултет - докторске студије, модул Српска књижевност

Београд

Основна школа „Лазар Саватић”

Земун

zeljkotesic83@gmail.com

\title{
НАСТАВНИКОВ САЈТ У НАСТАВИ СРПСКОГ ЈЕЗИКА И КЊИЖЕВНОСТИ'
}

\begin{abstract}
АПСТРАКТ
Рад проблематизује примену информационо-комуникационих технологија у настави српског језика и књижевности, а нарочито се осврће на могућности коришћења едукативног сајта чији је аутор (креатор) сам наставник. Указује се на предности оваквог приступа настави уз истицање сајта као помоћног средства које би требало да унапреди савремену наставу српског језика и књижевности. Наводе се примери примене наставниковог сајта у различитим областима које обухвата предмет Српски језик, у наставним и ваннаставним активностима, као и приликом припреме ученика за завршне испите. Учињен је посебан осврт на припрему ученика за анализу књижевних текстова уз помоћ наставниковог сајта, као и на могућности које се тичу обраде садржаја из граматике и правописа.
\end{abstract}

Кључне речи: информационо-комуникационе технологије, наставник, сајт, српски језик, књижевност, граматика, правопис.

\section{A TEACHER'S WEBSITE IN SERBIAN LANGUAGE AND LITERATURE CLASSES}

\begin{abstract}
1 Самостални истраживачки рад писан за потребе испитних обавеза у оквиру друге године докторских студија на Филолошком факултету у Београду (ментор - проф. др Зона Мркаљ).
\end{abstract}


The paper considers the application of informational and communication technologies in Serbian language and literature classes, and it especially points at the possibilities of using the educational website whose author (the creator) is the teacher himself. The paper shows the advantages of this approach in teaching, emphasizing the website as the teaching aid which should improve modern Serbian language and literature classes. There are the examples of applying the teacher's website in different fields comprised by Serbian language in both compulsory and elective school activities, as well as in preparation of students for their final exams. There has been a special review on the preparation of students for literature texts analysis using the teacher's website, as well as the possibilities related to processing grammar and orthography.

Key words: informational and communication technologies, teacher, website, Serbian language, literature, grammar, orthography.

\section{1. УВОД}

Технологије које су омогућиле бржи проток информација, лакшу комуникацију или значајно олакшање у свакој сфери савременог друштва све више проналазе своје место и у наставним процесима у основношколској, средњошколској и универзитетској пракси. Као такве савремене информационо-комуникационе технологије данас су незаобилазни чинилац рада модерног ученика/студента и наставника. Чињеница да се многе социолошке, антрополошке и културолошке теорије баве овим феноменима, поставља пред читаву јавност мноштво питања о половима деловања рачунара, телефона и других видова електронских изума који су постали део свакодневице. Овде мислимо првенствено на питања корисности и штетности оваквих тенденција и појава, те је наша намера примарно окренута првој поменутој релацији сагледавања наведеног феномена - позитивном аспекту информационо-комуникационих технологија и њиховој употребној вредности у раду са ученицима основне и средње школе.

Информационо-комуникационе технологије подразумевају различите системе функционисања рачунара и других електронских апарата којима се остварује могућност сабирања, складиштења и размене података.

Информациона технологија (IT) је технологија која користи рачунаре за прикупљање, обраду, чување, заштиту и пренос информација. Термину IT су придружене комуникационе технологије јер је данас незамислив рад с рачунаром ако он није повезан у мрежу, тако да се говори о информационој 
и комуникационој технологији (engl. Information and Communications Technology - ICT)" (Рендулић 2014: 1).

На овај начин чланови савременог друштва остварују своја права на едукацију и информисање, побољшавају своју информатичку писменост, а бивају укључени и у оно што се данас одређује као е-учење, односно учење при којем се користе рачунарски системи и могућности интернета.

Сведоци смо да се данас читава друштвена јавност пита о статусу детета у, како се то сада наглашава, ери рачунара, о томе колико се посредством модерних технологија ученик удаљава од књиге и поступног начина учења. Изражава се забринутост у вези са статусом традиционалне (штампане) књиге, очувања библиотека, издаваштва, а кроз све то стиже се и до сумње у опстанак традиционалне школе. Ипак, сматрамо, добро културном и образовном политиком и добрим планирањем и концептом савремене школе, могуће је пронаћи меру и активност преусмерити ка озбиљном разматрању употребне вредности модерних технологија како би се оне примениле управо тамо где сеже наша потреба за очувањем утемељених вредности. Ако се намера да се очува дух учења кроз сазнајно-стваралачки процес буде реализовала кроз озбиљне кораке образовних установа, неминовно је да ће у школи овог века бити простора за све видове учења, кроз симбиозу традиционалних и модерних приступа. Тако ће и ученик бити вођен кроз моделе који ће му омогућити да прати наставу осмишљену у духу свега што постоји од првих трагова писмености до модерних технолошких достигнућа.

Наставнику се данас пружа мноштво могућности да осмисли наставну праксу како би ученицима омогућио квалтетну и темељну надоградњу духа. Верујемо да се широки спектар могућности модерних технологија тако може применити и на начин да ученик време проведено испред рачунара искористи и као време учења, а не само забаве, али и да време забаве покаткад постане време учења и сазнавања, креације и продуктивног рада. У том смислу настава се све више окреће информационо-комуникационим технологијама и њиховој примени у школском окружењу, али и учењу код куће, а и сама методика наставе рачуна на удео овог феномена.

Једна од водећих дидактичко-методичких вредности информатичких технологија очитава се у њиховом комуникацијском аспекту. Зато информатички садржаји непосредно утичу на увећање и систематично организовано стручно информисање наставника (Павловић 2004: 55).

Наставник тако добија могућност да знатно унапреди своју праксу, а да истовремено испоштује утемељене принципе методске адекватности. Добија могућност да различитим видовима електронских и интернет 
садржаја конституише сопствени концепт методичког поступања и активности које ће ученицима којима предаје омогућити да наставне садржаје прихвате кроз ширу слику сагледавања. Таквим радом унапредиће, не само своју школску праксу, већ ће утицати и на стручно усавршавање својих колега. Чињеница да су многи садржаји из домена информационокомуникационих технологија јавни упућује на могућност да се директно или индиректно оствари повезивање наставника у својим намерама да наставни процес приближе савременом ученику. На тај начин доћи ће и до ревитализовања свих традиционалних и обавезних чинова наставног процеса - планирања наставе и афирмација образовних, васпитних и функционалних циљева наставе.

Настава српског језика и књижевности у великој мери налази могућности у примени информационо-комуникационих технологија. Разноврсне интернет-презентације, сајтови, форуми, друштвене мреже и други видови дистрибуције података представљају значајну помоћ како за наставнике тако и за ученике. Ипак, свест о томе да се управо на интернету може наћи много тога нетачног, непрецизног и непровереног, обавезује наставника да пажљиво, поступно и врло критички приступа доступним садржајима. Наравно, у том смислу, већа је опасност да ученици дођу у додир са нетачним подацима или текстовима који би могли да их погрешно усмере и криво науче. Данашњем ученику интернет је све доступнији, те наставник због тога мора и сам бити довољно информисан и упућен, али мора и личним активностима обезбедити да се ученик упути ка правилном селектовању доступних садржаја са интернета. У настави српског језика и књижевности, која у својој хетерогености активности и синкретичности поступака обухвата више области, оваква наставничка активност намеће се као драгоцена. Наставник би требало да буде онај који упућује на добре и проверене изворе, на сајтове званичних институција културе, уметности и науке, као и на друге корисне садржаје чији су аутори компетентни за конкретну област.

Као и за друге наставне предмете, тако је и у настави књижевности и српског језика могуће да наставник не буде ограничен једино на улогу цензора и селектора интернет страница и података, већ и да постане креатор различитих едукативних садржаја и интернет страница (сајтова) или да буде део друштвених мрежа од којих су неке намењене искључиво учењу и едукацији (нпр. друштвена мрежа Едмодо). Наставник ће моћи да целокупан наставни процес, од припреме часа, истраживачких задатака, приказивања различитих снимака које креира или преузима, до вредновања рада ученика и презентације ученичких радова реализује захваљујући 
оваквим могућностима. При томе неће занемарити непосредан школски рад ученика, као ни традиционална наставна средства и методе рада, јер ће примену информационо-комуникационих технологија посматрати као добро осмишљену надоградњу свега што већ примењује и што је методичка пракса утврдила као незаобилазно и значајно. Кроз овакав приступ наставник ће остати веран методологији наставе књижевности и српског језика. На часу hе се, на пример, примењивати дијалошка метода подстакнута нечим што ће бити приказано на наставниковом сајту, радиће се истраживачки задаци кроз методичко вођење и усмереност рада ученика. На овај начин биће нарочито афирмисана метода запажања и показивања, као врло значајна јер, како методичар Милија Николић истиче: „Чулним сусретањем са стварима, бићима и појавама човек упознаје своју суседност, успоставља основну слику света и стално стиче нова искуства" (Николић 1988: 56). Професор Николић даље говори о непосредном и посредном показивағу где наводи више примера који говоре о томе да се различитим аудио-визуелним садржајима потпомаже стварање комплексних утисака код ученика и да се тиме и сам процес сазнавања и учења унапређује. ,Чулна пријемчивост је услов за прихватање и препознавање знакова било ког семиотског приступа, па свакако и језичког.” (Исто: 59). Различитим могућностима модерних информационих технологија унапређује се наставна пракса највише захваљујући, рекли бисмо, сабирној и колажној природи интернет садржаја које креира сам наставник. Ако се посветимо искључиво могућностима наставниковг сајта који се креира и стално допуњује, сигурни смо да се могућностима оваквог, помоћног средства у настави, ученику помаже да буде активни учесник наставног процеса, али да буде и у уверењу да је настава у духу нечег што му је пријемчиво, па тако и занимљиво и за њега креирано.

Користећи сајт као вид комуникације са ученицима и користећи се погодностима оваквог облика интернет садржаја, наставник може да ученике подстиче да се заинтересују за неку област или конкретни садржај. Сајт који сам допуњује и усавршава тако може обухватити све етапе наставног процеса. Ако узмемо као пример проучавање књижевног дела које увек захтева посвећеност и ангажовање, доћи ћемо до закључка да се управо преко сајта ученик одлично може припремити за рад у току часа, али и за оно што следи након обраде, а то је даље, индивидуално трагање у свету књижевности.

У свим етапама ученик се мора систематски навикавати да у току читања и проучавања дела самостално решава бројна питања и задатке, 
који ће га у пуној мери емоционално и мисаоно ангажовати, пружити му задовољство и побудити истраживачку радозналост (Мркаљ 2010: 15).

Управо синкретичношћу садржаја сајта могу се створити услови да ученик самостално приступи задацима, питањима и осталим активностима које му наставник презентује преко своје интернет странице. Наравно, уз остале начине припреме и рада са ученицима, створиће се погодна истраживачка и стваралачка атмосфера, а ученик ће моћи да, захваљујући нечему што му је већ познато и блиско, или што (на пример на часовима информатике) тренутно учи, лакше допре до проверених података и добро осмишљених задатака.

\section{2. ИЗГЛЕД САЈТА И ОРГАНИЗАЦИЈА САДРЖАЈА}

Значај визуелног представљања важи и за сајт јер се добрим одабиром погодности, ефеката и апликација постиже израженија ученичка пажња и боље учење. Сви видови сајтова предвиђају постојање одређених страница и подстраница. Наставник треба да конципира сајт тако да га прилагоди свом начину рада, али и потребама ученика којима предаје. Оно што су незаобилазни сегменти наставниковог сајта, који се најчешће организују креирањем различитих страница, јесу области редовне наставе, али и ваннаставних активности. Дакле, странице би могле да буду организоване тако да представљају различите области (на пример: књижевност, граматика, правопис...), али се могу именовати и према различитим разредима (пети, шести, седми, осми), а да свака од тих страница садржи подстранице које даље гранају области или оно што је по програму у оквиру једног разреда.

Верујемо да би озбиљан наставнички сајт, уз језичко-стилску коректност текстова које нуди, требало да поседује и садржаје које бисмо одредили као основне, а да се тек након њиховог увођења наставник посвети конкретним наставним темама или јединицама, увођењу занимљивости и сл. Ови основни садржаји у вези су са тим да на сајту професора, односно предмета - курса који посећују, ученици проналазе детаљан наставни план са циљевима и исходима, списак литературе, основне и додатне, затим линковске везе ка другим важним и за дати предмет корисним сајтовима [...] (Павловић 2004: 57).

Наставник данас има могућност да од свог сајта начини изузетну базу садржаја и да омогући ученицима да за мање времена постигну више. На пример, може им, везом (линком) за одређени сајт помоћи да пронађу елек- 
тронско издање неке књиге коју не могу да пронађу у библиотеци или ће на сајт поставити књигу коју ученик може да чита и одштампа.

Уз наведене основне странице/теме сајта, битно је истаћи и то да данашњи сајтови (уз информациону) имају и наглашену комуникациону функцију, па нуде могућност да се ученик и наставник повежу и кроз размену порука, међусобно обавештавање, додатни рад зарад побољшања нивоа знања и вештина. Постоји и тзв. контакт форма која се може увести као засебна и тако истакнута страница, за ученике и њихове родитеље врло корисна.

На сајт се редовно постављају подаци, њима се може материјално опскрбити рад на часу, а садржаји из различитих области одлично се могу колажно представити и препоручити ученицима. Било да је реч о часовима књижевности, граматике, правописа или језичке културе, наставник треба да плански, селективно, осмишљено, али оригинално и занимљиво предочава садржаје коришћењем фотографија, телевизијских и радијских снимака, линеарних и нелинеарних текстова. Уз добро планирање, сви наставни садржаји постају изазовни за такво представљање. Организација тих садржаја свеприсутни је услов сврховитости едукативног сајта, а његов изглед један од значајних квантитативних параметара.

\section{3. НАСТАВНО ПРОУЧАВАЮЕ КЬИЖЕВНОСТИ УЗ КОРИШЋЕЊЕ НАСТАВНИКОВОГ САЈТА}

Данас је велики број интернет страница посвећен садржајима који се тичу књижевности. Као што је речено, нису сви ти садржаји, у погледу тачности података и компетентности аутора, легитимни извор информација, а нарочито не за младе који тек стичу знања. Због тога, наставник као стални модератор и селектор садржаја треба да личним ангажовањем и компетенцијама обезбеди добре (интернет) изворе информација. Није довољно (а некада је и опасно) ученицима дати задатак да нешто о одређеном писцу или делу прочитају на интернету. Потребно је бити прецизан, а тиме и педагошки одговоран и ученике јасно усмерити, указати им на назив сајта или његову адресу. Све то данас бива лакше ако имамо у виду да наставник располаже могућношћу да сам буде креатор едукативног сајта. Тако добија прилику да све садржаје које сматра погодним обједини и селектује, разврста и истакне на својој страници. Може да своју интернет страницу развије у својеврсну електронску припрему за час, односно да 
садржаје које припрема за одређени час посредством сајта истакне и објави како би ученицима били доступни.

Обрада књижевног текста представља сложен процес који, ако је ваљан, почиње од припреме за читање и приступ књижевном делу и опусу аутора тог дела. Ако је реч о ученицима средње школе који треба да се упознају са одређеном стилском формацијом и уметничком појавом или одређеним методолошким приступом у науци о књижевности, наставников посао се усложњава. Пре часа обраде потребно је различитим активностима ученике мотивисати да читају дело. То је значајно, било да је реч о краткој лирској песми или о роману као што је Толстојева Ана Карењина, јер треба ослушнути сензибилитет ученика, њихов узрасни и интелектуални ниво и интересовања.

У свом занимљивом тексту Глагол читати не подноси императив Данијел Пенак пише: „Глагол читати не подноси императив. Исти отпор према њему имају и неки други глаголи, као „волети” или „сањарити”...“ (Пенек 2008: 53)² Касније додаје: „Треба читати; то је погрешан начин убеђивања за уши младих људи. Без обзира на сјајне доказе које им наводимо... погрешан начин убеђивања" (Исто: 56). Ако прихватимо овакав приступ као исправан, доћи ћемо у позицију да своју припремну активност осмислимо што темељније и опрезније. Ако користимо мноштво различитих могућности, у томе ћемо и успети. Овде ћемо покушати да укажемо на то како би наставник, коришћењем свог сајта, могао да подстакне ученике да читају књижевна дела. При томе, намера нам је да се окренемо читању, не само обавезне школске лектире, већ и књигама које наставник препоручује или их ученик (уз добро усмерење) сам проналази. ${ }^{3}$

Сајт наставнику пружа мноштво могућности. На једној страници за своје ученике може припремити различите материјале посвећене једном писцу или делу. Ако као пример узмемо обраду приповетке Све ће то народ позлатити у осмом разреду или обраду приповетке Први пут с оцем на јутрење у првом разреду средње школе, приметићемо да се ученици за

2 У овом занимљивом, али и (за наставнике књижевности) изузетно поучном тексту истиче се значај наставникове улоге на пољу мотивисања ученика да читају. Кроз причу о професору књижевности који „није кљукао знањем“, него ,једноставно пружао оно што зна“ истиче се значај ненаметљивог подстицања ученика да читају књиге. Дакле, овде се, сматрамо оправдано, тврди како ће читати и волети да чита само онај који је лепоту те активности открио кроз усађивање љубави и откривање света књижевности, а не захваљујући некаквим принудама или само празним говором о значају читања.

3 О теми читања у слободно време, односно о читању књига ван наставног програма говориће се у целини посвећеној примени сајта у ваннаставним активностима. 
читање овог дела пре часова обраде могу припремити на више начина. Наставник на једној страници може поставити биографске податке о аутору Лази Лазаревићу, визуелним истицањем може указати на Лазаревићево бављење лекарском праксом, као и на његове занимљиве биографске податке. Као занимљив прилог на сајту могу се наћи и одломци филмова насталих на основу садржаја приповедака овог писца. Било би, такође, занимљиво да наставник на сајт истакне одломак из романа Икона Љубице Арсић који говори о Лазином приватном животу. Иако би се последњој од ових активности могло замерити да Лазаревићевом делу приступа позитивистички, верујемо у сврсисходност таквог поступка у наставној пракси, у делу припреме, али не и приликом тумачења дела. Даље, наставник овде може поставити истраживачке припремне задатке који ће бити у вези како са осталим појединостима са сајта тако и са самим делом ка коме ће водити ученике. Шта више, први задаци би свакако требало да буду у служби подстицања ученика да упознају Лазаревићево дело и да прочитају његову приповетку из наставног програма.

Роман, као обимна књижевна врста, захтева добро осмишљену припрему и наставника и ученика. Како је обрада романа предвиђена за најмање два школска часа, онда би се, свакако, и припрема странице сајта одвијала поступно и кроз предвиђене кораке. Наставник би могао да, након сваког часа обраде, ученике обавести да ће се тог дана на сајту појавити нови задаци који ће их увести у садржај следећег часа обраде. На сајту ће наставник, нарочито за ученике средње школе, објавити делове одређених студија о роману и сл., па ће им тиме развити и однос према секундарној литератури. За следећи час им може донети и одштампане примерке одломака из студија уз афирмацију рада на тексту.

Епска песма, као и проза, нуди могућност да се страница сајта исписује тако што ће се пратити пут анализе. Како ученици основних школа обрађују усмену епику по тематским круговима, наставник би могао да врло лепо осмисли садржај сајта у вези са, на пример, песмама о Марку Краљевићу, Косовском боју и др. Тако би овде могла да буде заступљена подједнака активност ученика и наставника. Наставник би припремио адекватну методичку апаратуру, а ученици би и сами били истраживачи и креатори странице сајта. Страница посвећена Марку Краљевићу могла би да постане ризница израђена активношћу свих ученика и наставника. Свако би могао да добије радне задатке применом групног облика рада и свака би се група бавила одређеним проблемом (1. историјски лик Марка Краљевића, 2) народна легенда о Марку, 3) елементи Маркове епске биографије, 4) како 
је Марко представљен на фресци из манастира у Скопљу, како на портрету који је насликала Мина Караџић и др.).

Тумачење лирске песме свакако представља особену припрему јер је њено тумачење често захтевније за ученике. Потребно је да се упознају са тематско-мотивским аспектом песме, да продру у њене семантичке видове, али најпре да је осете као ритмичко-мелодијски склад и нешто што треба да се касније, зависно од плана наставника или интересовања ученика, рецитује или гласно чита. Зато је неопходно да се и сама страница (или део странице) сајта, посвећена одређеној лирској песми, осмисли тако да млади читалац буде уведен у поетски доживљај на особен и подстицајан начин. Тако ће се на страници наћи текст песме, подаци о аутору, истраживачки задаци, али и све оно што ће употпунити ученички доживљај и подстаћи га да се посвети песми. На пример, приликом тумачења песме Плава звезда Мирослава Антића неопходно је да наставник на страницу сајта, уз претходно наведено, постави и снимак музичког извођења ове песме, као и неку узорну рецитацију. Врло је битно да се тај део странице сајта и визуелно добро осмисли коришћењем различитих боја, облика и сличног. Наставник претходно и сам може креирати видео-снимак у коме би (комбинацијом пригодне класичне музике и адекватних фотографија уз текст песме) појачао учеников доживљај поетског дела. Чини нам се да би, захваљујући томе, и ученички одговори на часу, у вези са утисцима и доживљајем одређених стихова или песничких слика, могли да буду продубљенији и снажнији.

Приликом комплетног процеса наставне анализе лирске песме наставник има могућност да допуњује садржај сајта. На пример, ако је након часова обраде песме Плава звезда ученицима дато да за домаћи задатак пишу састав о теми $У$ потрази за својом звездом, могли би се на сајт поставити одломци ученичких радова које сами одаберу и слично. Тако би се и анализа песме учинила комплетнијом и садржајнијом. Слично се може чинити и приликом анализе осталих књижевних врста. Ученици могу писати препоруке за читање одређеног дела, могу писати наставак дела (нпр. бајке), илустровати дела. Наставник све такве активности лако може презентовати на свом сајту и, верујемо, учинити да се и ученици осећају као креатори и вредни учесници у настави.

Коришћење сајта у току часова књижевности или приликом ученикових активности и припреме код куће никако не сме да искључи коришћење уџбеничке литературе. Ако је реч о анализи лирске песме ученици се упућују на читанке, збирку из које је та песма и др., али се и то може укључити у презентацију на сајту. Тако ће наставни процес бити заокружен и исходи тог процеса ићи ће ка знањима и вештинама које нису засноване 
на догматско-репродуктивним моделима, већ ка стваралачком приступу који подстиче ученичку когницију. Књижевна дела ће на овај начин ученицима бити представљена као уметничке творевне вредне њихове пажње, а сам час и оно што му претходи или што иза њега следи биће драгоцена ученичка искуства и трагања.

\section{4. КОРИШЋЕЮЕ НАСТАВНИКОВОГ САЈТА У НАСТАВИ ГРАМАТИКЕ, ПРАВОПИСА И ЈЕЗИЧКЕ КУЛТУРЕ}

Уз проучавање књижевности у основној и средњој школи пажња се на часовима у оквиру предмета Српски језик и Српски језик и књижевност посвећује и бављењу матерњим језиком, правописом и језичком културом. Наставник би требало да садржаје из језика, правописа и језичке културе увек доводи у везу са садржајима из књижевности. Као што књижевни текст може бити предложак за језичку анализу, тако и појмови из језика бивају функционални приликом анализе књижевних дела. Наставников сајт зато може бити организован, као што је речено, на више начина, али је неопходно да се приликом његовог структурирања (нарочито када су одвојене странице посвећене књижевности и језику) стално истиче веза између језика и књижевности.

Примери повезивања оваквих садржаја, као и примери представљања искључиво граматичких или правописних садржаја на сајту су бројни. Наставник на занимљив и оригиналан начин може да презентује нове граматичке садржаје, да врши обнављање обрађеног или да на сајту објављује примере честих граматичких или правописних грешака. Данашњи сајтови усавршени су у тој мери да нуде и могућности објављивања домаћих задатака које ученици треба да раде, па да одговоре шаљу наставнику. Тако модернизован домаћи задатак ученика ће подсетити на неке рачунарске игрице и сличне садржаје. Многи задаци су, такође, осмишљени у виду квиза, уз добијање информације о тачности одговора и сл. То је изузетно корисно за ученике који се спремају за такмичења или за завршни испит. ${ }^{4}$

На сајту наставник може да, као што смо то показали и на примеру књижевних дела, планира читав процес обраде и утврђивања одређених

4 Тако постоји могућност да задатке из збирке задатака за завршни испит ученици решавају и посредством рачунара. Заправо, задатке је за решавање на рачунару обликовао Бошко Симеуновић, наставник техничког и информатичког образовања у Основној школи „Татомир Анђелић” из Мрчајеваца. Ученик бира област или ниво (основни, средњи или напредни) и задатке решава означавањем тачних одговора, дописивањем текста и слично. 
граматичких садржаја. Када обрађује гласовни систем српског језика, за ученике ће на једном месту припремити поделе гласова. При томе ће користити и граматику, радну свеску и друге приручнике. Ученици, такође, могу да смисле реченице за памћење група гласова, а да их наставник постави на сајт. Приликом припреме за часове посвећене историји српског језика наставник ће садржајима сајта надоместити могуће недостатке уџбеника или ће увести слике, мапе и др. што ће ученицима помоћи да разумеју ову област. Овде се може успоставити корелација са историјом и географијом, а сви продукти рада могу наћи свој простор на страници сајта. Наставник, такође, може да постави и видео-садржаје (нпр. одломке из телевизијске серије о Вуку Караџићу), фотографије старих текстова, као и читаве књиге које може да пронађе на другим сајтовима, као што су сајт Народне библиотеке Србије и други.

Када креира сајт, наставник никако не би требало да одређене граматичке вежбе представља кроз схематизоване и једноставне задатке.

Када се за вежбања користи текст, онда ваља што више избегавати формалистичке и оголеле захтеве да се поједине речи, облици и реченице само проналазе у тексту, подвлаче и преписују (Николић 1988: 467).

Сајт може да пружи и пример теста (какав ће ученици, рецимо, решавати у току завршног испита), али је методички корисније упутити ученике на различите комуникативне ситуације кроз које ће уочити некакво граматичко или правописно правили и сл. На пример, приликом утврђивања правила о писању великог слова или речце не занимљиво је поставити на сајт фотографије натписа (називи улица, обавештења на радњама и сл.) у којима се крију грешке. Од ученика ће се захтевати да уочи грешке, али ће се затим повести разговор и о томе како смо свакодневни сведоци оваквих језичких огрешења, а разговараће се и о значају поштовања граматике и правописа. На тај начин ученици ће језичке појаве сагледавати кроз њихову свакодневну, комункитавну функцију.

Правописна правила су нешто што би ученик требало стално да усваја, она се морају ненаметљиво предочавати, упућивати на њихов шири значај, а никако их не треба представљати као нешто што се усваја зарад пуког познавања. И овде су могућности сајта вишеструке. Ученици могу да креирају песме о значају правописа, да исписују дијалоге у којима се јавља грешка и исправка грешке, да само проналазе примере погрешне употребе и да све то презентују на часу, а затим и на наставниковом сајту. Како се на сајту све архивира, наставник може да након извесног времена, када се опет буде бавио сличном проблематиком, приказивањем архивиране странице подсети ученике на оно што су сами осмислили и урадили. Због тога 
се значај сајта огледа и у чињеници да он може да представља скуп многих активности наставника и ученика и да се након часова обраде утврђивање изврши управо сагледавањем онога што је на претходним часовима урађено и објављено на сајту.

Предочени примери свакако могу послужити и као модел приликом обраде другачијих садржаја. Тако час језичке културе у петом разреду, посвећен писању вести, може бити занимљиво осмишљен и реализован уз коришћење припремљених материјала са наставниковог сајта (нпр. снимак телевизијске вести, фотографија исечка из новина/ новинских вести, подаци на основу којих ученици треба да напишу вест и сл.). Функционалност сајта овде би била и у томе што ће наставник врло сликовито представити вест; омогућиће ученицима да сами дођу до закључка шта је вест и које податке мора да обједини, а пошто је све на једном месту (страници сајта) ученици ће имати више времена за вежбање (на пример да у току другог дела часа ураде задатке из радне свеске, напишу своју вест и др.). Овакви садржаји могу бити и могућност за повезивање језика, књижевности, правописа, вештине читања и разумевања прочитаног и сл. Најзад, оваква настава ће свакако профилисати и креативног наставника, онога који је пре свега у позицији организатора часа, човека који мотивише, моделира, помаже, истражује, иницира, подстиче, прати усмерава и стално трага за новим видовима организације, налазећи и сам задовољство у својој креативности и креативности својих ученика (Маринковић 1994: 19).

Наставник добрим одабиром примера и њиховом презентацијом поспешује рад ученика, прати напредак сваког ученика и сагледава остваривање стандарда образовања и васпитања.

\section{5. ПРИМЕНА НАСТАВНИКОВОГ САЈТА У ВАННАСТАВНИМ АКТИВНОСТИМА}

Функционалност примене информационо-комуникационих технологија у настави не огледа се само приликом редовне наставе, већ и кроз друге видове образовно-васпитног рада. Допунска и додатна настава свакако могу бити добро осмишљене и потпомогнуте коришћењем сајта. Beћ је поменуто да данашњи едукативни сајтови нуде могућност задавања (домаћих) задатака које ученик решава и своје одговоре шаље наставнику. Тако се остварује и боља индивидуализација у раду са ученицима, било да имају потешкоће приликом учења било да се припремају за такмичење. Наставник, такође, може да поставља на сајт и примере тестова за такмичења, 
програме такмичења и слично, па ће ученицима обезбедити лакшу припремy.

Ипак, посебну пажњу треба посветити примени сајта приликом рада у оквиру различитих секција, јер се у раду секција највећа пажња придаје ученичким радовима. На страницама наставниковог сајта, посвећеним радовима ученика, улога наставника треба да буде првенствено уредничка и менторска. Због тога би странице посвећене раду секција требало да буду кључне на сајту из више разлога. Најпре, на тај начин било би афирмисано дечје стваралаштво и њихова креативност, што би делотворно деловало и на активност ученика у току редовне наставе, такође, обазбедило би се и задовољство родитеља, а свакако би се постигла и промоција школе.

„Литерарна секција има за циљ запажање, развијање и усавршавање посебног дара ученика, и као таква ова је област усмерена ка индивидуалном раду” (Живковић 2007: 52). Управо због тога сајт у раду литерарне секције може да има изузетно место јер служи за промоцију стваралаштва ученика, а представља и базу радова који би се касније могли послати на литерарне конкурсе или за часописе. Радови се могу груписати тематски, жанровски, узрасно итд. Ипак, њихова појава на сајту представљаће начин да се ученик мотивише, усмери и да се његов самостални рад промовише као позитиван пример/ вредност. Такође, како је за литерарну секцију, осим писања, врло значајно и читање и однос према књизи, наставник ће имати могућност да уз помоћ сајта својим ученицима представи различите писце и књиге, да их усмери ка сајтовима издавача и библиотека. Сајт може послужити и као начин обједињавања различитих литерарних конкурса за ученике, може најавити књижевно вече које ученици припремају или се на њему може објавити снимак књижевне вечери. У таквом мноштву активности, ученик ће добити активну сарадничку улогу, а његов пример може да буде подстицајан и за остале ученике.

У раду осталих секција, као што су новинарска, драмска, библиотечка и друге, сајт налази примену, да ли као посвећен искључиво једној секцији или у оквиру осталих ваннаставних и наставних активности. Рецитаторима се на једном месту (на наставниковом сајту) могу понудити добри примери говорништва, наступи добрих рецитатора и тако даље. Чланови драмске секције могу да постављају снимке својих представа или фотографије настале приликом извођења представе. Ипак, рад новинарске секције школе може да се одлично презентује посредством сајта, шта више сајт може да постане електронски пандан штампаног часописа, јер се рубрике могу врло једноставно представити помоћу страница и подстраница сајта. Тако ће часопис превазићи врло честе финансијске и друге баријере. 
Као једноставан за коришћење и данас лако доступан облик садржаја на интернету сајт у ваннаставним активностима може да буде врло захвалан. Стога сматрамо да је у раду савремене литерарне или новинарске секције незаобилазан уз све раније моделе рада ових секција, јер представља надоградњу која, као што је истакнуто, превазилази различите баријере, а успева да афирмише ученика као креативног појединца који кроз такву афирмацију гради свест о себи и спознаје своја интересовања.

\section{6. ЗАКЉУЧАК}

Без претензије да се примена информационо-комуникационих технологија представи као кључна у раду наставника, покушали смо да испитивањем различитих могућности наставниковог сајта и сагледавањем примера где би се те могућности оствариле, истакнемо значај овог облика садржаја које проналазимо на интернету. Сајт се ипак намеће као својеврсни вид базе материјала које креирају ученици и наставници. Његови су улога и значај у надоградњи традиционалних облика рада и начина функционисања часа. Такође, вредност му се огледа и у јавности објављених садржаја који тако превазилазе оквире једног одељења или школе и бивају корисни и осталима који су посетиоци сајта.

Више пута истакнута педагошка улога сајта у највећој мери огледа се у томе што ће ученик, управо кроз усмереност ка наставниковом сајту, бити боље заштићен од садржаја који су непроверени или износе нетачне податке. Проблем пуког прихватања различитих интерпретација књижевних дела присутних на интернету, нарочито у оквирима средњошколске популације, могао би се прилично решити постојањем наставникове странице на интернету. Тиме би до ученика дошла валидна, научно поткрепљена, али и тумачења која су прилагођена ученику или писана управо за ученике. Тако не бисмо долазили у ситуацију да основци и средњошколци, приликом писања писмених задатака о темама које захтевају тумачење књижевних дела, користе или цитирају неадекватне текстове.

Наставнички рад могао би оваквим помоћним средством да буде побољшан, међутим, израда сајта требало би да буде (у низу активности и поступака) вршна тачка наставничке праксе. Пре тога, битно је добро планирање наставе, афирмација различитих проверених наставних метода, као и различитих облика рада. Тек уз испуњење ових темељних предуслова, наставник може да правилно употреби могућности сајта у настави. Употре- 
ба тих могућности и учење на овом пољу постаје један од видова стручног усавршавања наставника, па тако и усавршавања опште школске праксе.

\section{ЛИТЕРАТУРА}

Маринковић, С. (1994). Методика креативне наставе српског језика и къижевности. Београд: Креативни центар. [Marinković, S. (1994). Metodika kreativne nastave srpskog jezika $i$ književnosti. Beograd: Kreativni centar.]

Мркаљ, 3. (2010). Планирање у настави. Београд: Klett. [Mrkalj, Z. (2010). Planiranje u nastavi. Beograd: Klett.]

Николић, М. (1988). Методика наставе српскохрватског језика и књижевности. Београд: Завод за уџбенике и наставна средства. [Nikolić, M. (1988). Metodika nastave srpskohrvatskog jezika $i$ književnosti. Beograd: Zavod za udžbenike i nastavna sredstva.]

Павловић, M. (2004). „Дидактичко-методичке вредности и васпитне могућности савремене информатичке технологије у настави и образовању (у предметним областима књижевности, језика и друштвених наука)”. Школски час 1: 54-64. [Pavlović, M. (2004). „Didaktičkometodičke vrednosti i vaspitne mogućnosti savremene informatičke tehnologije u nastavi i obrazovanju (u predmetnim oblastima književnosti, jezika i društvenih nauka)". Školski čas 1: 54-64.]

Rendulić, D. I. (2014). ITdesk.info - projekat računarske e-edukacije sa slobodnim pristupom - Priručnik za digitalnu pismenost. Zagreb: Otvoreno društvo za razmenu ideja.

Живковић, В. (2007). „Видови функционисања литерарне секције”. Школски час 3/4: 52-58. [Živković, V. (2007). ,Vidovi funkcionisanja literarne sekcije". Školski čas 3/4: 52-58.] 


\author{
Željko Tešić \\ University of Belgrade \\ Faculty of Philosophy - doctoral studies, module Serbian Literature \\ Belgrade \\ Primary School „Lazar Savatić“ \\ Zemun \\ zeljkotesic83@gmail.com
}

\title{
A TEACHER'S WEBSITE IN SERBIAN LANGUAGE AND LITERATURE CLASSES
}

\section{Summary}

The paper considers the application of informational and communication technologies in Serbian language and literature classes, and it especially points at the possibilities of using the educational website whose author (the creator) is the teacher himself. The paper shows the advantages of this approach in teaching, emphasizing the website as the teaching aid which should improve modern Serbian language and literature classes. There are the examples of applying the teacher's website in different fields comprised by Serbian language in both compulsory and elective school activities, as well as in preparation of students for their final exams. There has been a special review on the preparation of students for literature texts analysis using the teacher's website, as well as the possibilities related to processing grammar and orthography.

Key words: informational and communication technologies, teacher, website, Serbian language, literature, grammar, orthography.

Примљено: 1. 4. 2016.

Прихваћено: 23. 4. 2016. 